\title{
CARBON FLUXES IN KARST AQUIFERS: SOURCES, SINKS, AND THE EFFECT OF STORM FLOW
}

\author{
TOK OGLJIKA V KRAŠKIH VODONOSNIKIH: IZVORI, \\ PONORI IN UČINKI POPLAVNIH TOKOV
}

William B. WHITE ${ }^{1}$

\begin{abstract}
UDC 546.26:551.444

William B. White: Carbon fluxes in Karst aquifers: Sources, sinks, and the effect of storm flow

An effective carbon loading can be calculated from measured alkalinity and $\mathrm{pH}$ of karst waters. The carbon loading is independent of the degree of saturation of the water and does not depend on the water being in equilibrium with the carbonate wall rock. A substantial data base of spring water analyses accumulated by students over the past 40 years has been used to probe the $\mathrm{CO}_{2}$ generation, transport, and storage in a variety of drainage basins that feed karst springs. Carbon loading in the water exiting karst drainage basins depends on the rate of $\mathrm{CO}_{2}$ generation in the soils of the catchment areas and on the partitioning between $\mathrm{CO}_{2}$ dissolved in infiltration water and $\mathrm{CO}_{2}$ lost by diffusion upward to the atmosphere. For any given drainage basin there are also influences due to vegetative cover, soil type, and the fraction of the water provided by sinking stream recharge. Losses of $\mathrm{CO}_{2}$ back to the atmosphere occur by speleothem deposition in air-filled caves, by degassing of $\mathrm{CO}_{2}$ in spring runs, and by tufa deposition in spring runs. There are seasonal cycles of $\mathrm{CO}_{2}$ generation that relate growing season and contrasts in winter/summer rates of $\mathrm{CO}_{2}$ generation. Overall, it appears that karst aquifers are a net, but leaky, sink for atmospheric $\mathrm{CO}_{2}$.

Keywords: $\mathrm{CO}_{2}$, karst aquifers, springs, carbon loading.
\end{abstract}

Izvleček

UDK 546.26:551.444

William B. White: Tok ogljika v kraških vodonosnikih: izvori, ponori in učinki poplavnih tokov

Vsebnost ogljika (carbon loading [ g/l]) v kraških vodah lahko določimo z meritvijo alkalnosti in $\mathrm{pH}$. Vsebnost je neodvisna od stopnje nasičenja in stanja ravnotežja vode glede na karbonatno matično kamnino. Za vrednotenje izvorov, prenosa in skladiščenja $\mathrm{CO}_{2}$, smo uporabili obsežno bazo geokemijskih podatkov iz več kraških sistemov v ZDA. Ti podatki so bili pridobljeni v okviru različnih študentskih del v zadnjih 40 letih. Vsebnost ogljika v kraških vodah je odvisna od intenzivnosti produkcije $\mathrm{CO}_{2} \mathrm{v}$ prsti kraškega zaledja in razmerja med delom $\mathrm{CO}_{2}$, ki se porabi za raztapljanje karbonatov in delom $\mathrm{CO}_{2}$, ki se $z$ difuzijo vrne nazaj $v$ atmosfero. Pri tem so pomembni vplivi vegetacije, tipa prsti in delež vode, ki jo $\mathrm{v}$ zaledje prinesejo ponornice. Izgube $\mathrm{CO}_{2} \mathrm{v}$ atmosfero nastajajo z izločanjem sige, $\mathrm{z}$ razplinjanjem $\mathrm{CO}_{2}$ na izvirih in izločanjem lehnjaka. Izvori, transport in ponori $\mathrm{CO}_{2}$ so tudi sezonsko pogojeni. Če povzamemo, je kraški vodonosnik neto, vendar puščajoči, ponor $\mathrm{CO}_{2}$.

Ključne besede: $\mathrm{CO}_{2}$, kraški vodonosnik, izviri, vsebnost ogljika.

\section{INTRODUCTION}

Concern over rising $\mathrm{CO}_{2}$ levels in the atmosphere and their probable influence on climate has prompted an intense interest in the global cycle of $\mathrm{CO}_{2}$ including both natural and anthropogenic sources and sinks. Rock weathering by chemical reactions of silicate minerals with $\mathrm{CO}_{2}$-bearing solutions has been identified as a $\mathrm{CO}_{2}$

\footnotetext{
${ }^{1}$ Department of Geosciences, The Pennsylvania State University, Deike Building, University Park, PA 16802 USA, e-mail: wbw2@psu.edu
}

Received/Prejeto: 13.2.2013 
sink and therefore a site of carbon sequestration (Gaillardet et al. 1999; Franck et al. 1999; Kump et al. 2000; Moosdorf et al. 2011). Rock weathering in carbonate terrain remains somewhat enigmatic. Dissolution of limestone and dolomite by $\mathrm{CO}_{2}$-bearing ground waters consumes $\mathrm{CO}_{2}$ and has been proposed as an explanation for about one fourth of an unknown sink in the continental biosphere (Gombert 2002). However, other karstic processes can release the $\mathrm{CO}_{2}$ back into the atmosphere with the net effect of transferring carbon but not sequestering it. As a consequence, some authors discount carbonate rock weathering as an important contributor to the carbon flux. Earlier estimates (Liu \& Zhao 2000) assign about one fourth of the carbon flux in karst terrain to a carbon sink with the remaining three fourths recycled by rainfall and atmospheric circulation. Later calculations by Liu et al. (2011) argue that the $\mathrm{CO}_{2}$ sink from carbonate rock weathering has been underestimated.

There have been many investigations of the chemistry of karst waters but most are concerned with saturation state and the dissolution and precipitation of carbonate minerals. The present study uses the same data recalculated as total dissolved inorganic carbon to probe the various controlling influences and to determine whether it is possible to tally the karst components of the $\mathrm{CO}_{2}$ budget. These calculations apply to carbon fluxes in individual karstic drainage basins and do not address carbon fluxes on a global scale. However, when the sources and sinks are added up, should karst aquifers be included as a $\mathrm{CO}_{2}$ sink in the global carbon budget?

\section{CARBON FLUXES IN KARST AQUIFERS: THE CONCEPTUAL MODEL}

Superficially, the function of karst processes in $\mathrm{CO}_{2}$ transport and sequestration can be described by the reaction

$\mathrm{CaCO}_{3}+\mathrm{CO}_{2}+\mathrm{H}_{2} \mathrm{O} \rightarrow 2 \mathrm{HCO}_{3}^{-}+\mathrm{Ca}^{2+}$

For each mole of calcite dissolved, a mole of $\mathrm{CO}_{2}$ is extracted from the environment and a mole of $\mathrm{CO}_{2}$ is released from long-term sequestration in the carbonate rock. The carbon is transported through the karst drainage basin mainly as dissolved $\mathrm{CO}_{2}$ and bicarbonate ions carried in solution to a spring and then taken out of the basin by surface streams. Unfortunately, the reaction above and other reactions in carbonate chemistry are easily reversible. The actual carbon flux through karst aquifers is much more complicated and involves both sources and sinks. Most importantly with regard to karst aquifers as overall $\mathrm{CO}_{2}$ sinks is that the systems are leaky and there are multiple pathways by which $\mathrm{CO}_{2}$ consumed in carbonate reactions can be returned to the atmosphere. Fig. 1 gives a schematic of the most important interactions and flow paths.

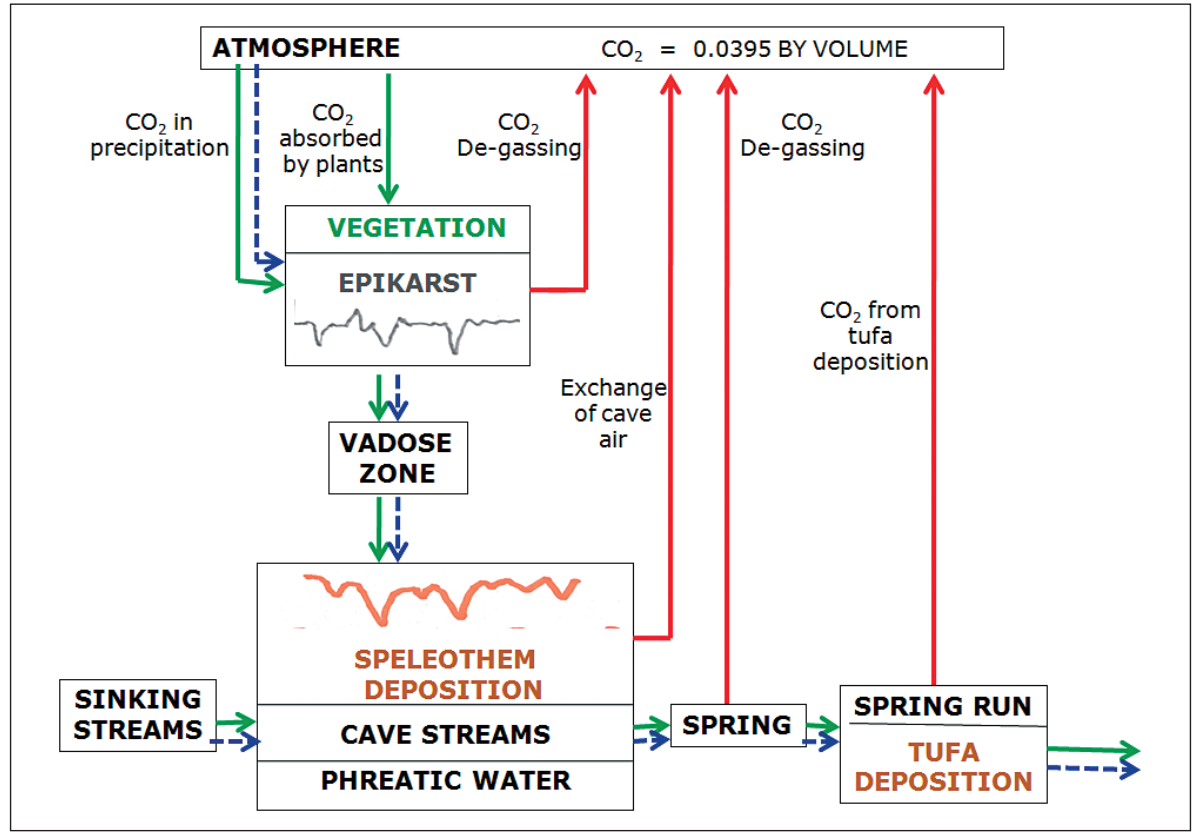

Fig. 1: Flow sheet for the movement of carbon dioxide through karst aquifers. Green lines represent a flux of $\mathrm{CO}_{2}$ into the aquifer; red lines represent loss of $\mathrm{CO}_{2}$ back to the atmosphere. Green lines with a parallel dashed blue line are pathways in which the carbon is transported in solution. 
The background reservoir for $\mathrm{CO}_{2}$ budgets is the atmosphere. The $\mathrm{CO}_{2}$ concentration in the atmosphere as of 2012 is 0.0395 volume percent. This value is drawn from the $\mathrm{CO}_{2}$ records collected at Mauna Loa observatory, Hawaii. The Mauna Loa data are available on the National Oceanographic and Atmospheric Administration website.

Atmospheric carbon dioxide dissolves in atmospheric moisture and is carried to the ground by rainfall. Even this seemingly simple process is more complicated than it seems. Some portion of the rainfall evaporates taking both the water and the dissolved $\mathrm{CO}_{2}$ back into the atmosphere. Some portion is taken up by growing plants with a portion of the water returned to the atmosphere by transpiration. The $\mathrm{CO}_{2}$ in this portion may be retained by the plants as part of their biomass. Finally, a third portion of the rainfall infiltrates deeper into the soil, carrying its load of dissolved $\mathrm{CO}_{2}$ deeper into the epikarst.

Direct extraction from the atmosphere is not the primary source of $\mathrm{CO}_{2}$ driving carbonate rock dissolution. $\mathrm{CO}_{2}$ concentrations in soils typically range from fractions of a percent to as high as ten percent due to $\mathrm{CO}_{2}$ from plant roots, from microbial activity, and from decaying vegetation. Thus the carbon flux through karst aquifers is, in large part, spun off from the vegetative carbon cycle.

Photosynthesizing plants draw $\mathrm{CO}_{2}$ from the atmosphere and sequester the carbon temporarily as cellulose and other plant components (their bulk composition represented as $\mathrm{CH}_{2} \mathrm{O}$ ). In rough mass-balance terms:

$\mathrm{CO}_{2}+\mathrm{H}_{2} \mathrm{O} \rightarrow \mathrm{CH}_{2} \mathrm{O}+\mathrm{O}_{2}$

When the vegetation dies, the cellulose oxidizes and decays (the reverse of equation (2)), releasing the stored carbon as $\mathrm{CO}_{2}$. The decay of plant material in the epikarst provides the primary source of carbon that is fed into the karst system. A fraction of the $\mathrm{CO}_{2}$ withdrawn from the atmosphere by plant growth is transferred to the karst system and not discharged back to the atmosphere thus breaking what would otherwise be a closed cycle.

The main part of the dissolutional denudation of karst takes place where infiltration water from the epikarst reaches the underlying carbonate bedrock. Here is where dissolved carbon dioxide extracts additional carbon from the carbonate rocks and releases the reaction products, mostly the bicarbonate ion, into water descending through the vadose zone. If the pathways through the vadose zone consist mostly of joints and fractures, there will be little gain or loss of $\mathrm{CO}_{2}$ as the water descends to the water table although it is possible that organic matter, carried downward through open fractures, provides a $\mathrm{CO}_{2}$ source at depth (Wood, 1985). If the descending vadose water happens to intersect an open cave passage in which the $\mathrm{CO}_{2}$ pressure is less than that of the vadose water, $\mathrm{CO}_{2}$ will be degassed resulting in the re-precipitation of dissolved calcite. Half of the transported carbon will be re-sequestered as speleothem calcite but the other half will be released into the cave atmosphere. $\mathrm{CO}_{2}$ in the cave atmosphere can be dissolved in cave stream waters if these waters are not already saturated or may be removed to the surface atmosphere by diffusion or by circulating air currents.

$\mathrm{CO}_{2}$ is also carried into karst aquifers by sinking surface streams. Concentrations of $\mathrm{CO}_{2}$ depend on the source of the water in the sinking surface stream whether the catchments are made up of forest, grassland, agricultural land, or urban areas, and also what fraction of the stream flow is contributed by ground water and what fracture by overland runoff.

Spring discharges are not the end of the story for carbon transport. Some coastal karst springs discharge directly into the ocean, some are located on the banks of major rivers, but most karst springs feed into small tributaries (spring runs) that flow as surface streams for considerable distances before linking to the main paths of the surface drainage system. The spring run must be considered part of the karst system because the water often undergoes chemical changes downstream from the spring. If the spring water, even if undersaturated, has a calculated $\mathrm{CO}_{2}$ partial pressure higher than that of the atmosphere, $\mathrm{CO}_{2}$ will be degassed, the $\mathrm{pH}$ and saturation index will rise, and some of the dissolved $\mathrm{CO}_{2}$ will be returned to the atmosphere. If the saturation index becomes positive, calcium carbonate may be deposited as tufa, returning still more $\mathrm{CO}_{2}$ to the atmosphere.

The conceptual model presented in Fig. 1 ends where the spring run leaves the carbonate basin. There are more sources and sinks for carbon along the route through the surface river system to the ocean. In the ocean, the dissolved carbonates can be precipitated by marine organisms, again releasing $\mathrm{CO}_{2}$ that contributes to ocean acidification. Although necessary for globalscale models, downstream processes are not considered further in this paper. 


\section{CALCULATION OF CARBON LOADING AND FLUXES}

The carbonate geochemistry needed for these calculations is discussed in detail in White (1988), Langmuir (1997), or Drever (1997).

The total inorganic carbon in solution is simply the sum of all dissolved carbon species.

$$
[\text { Carbon }]=\left[\mathrm{CO}_{2}(\mathrm{aq})\right]+\left[\mathrm{H}_{2} \mathrm{CO}_{3}\right]+\left[\mathrm{HCO}_{3}^{-}\right]+\left[\mathrm{CO}_{3}^{2-}\right]
$$

where the quantities in brackets are molar concentrations. The first two terms are taken together as $\mathrm{H}_{2} \mathrm{CO}_{3}$. The concentration of the carbonate ion in the $\mathrm{pH}$ range of karst waters is usually negligible.

The combined aqueous $\mathrm{CO}_{2}$ and neutral carbonic acid can be calculated from alkalinity and $\mathrm{pH}$

$\left[\mathrm{H}_{2} \mathrm{CO}_{3}\right]=\frac{\left[\mathrm{HCO}_{3}^{-}\right] \gamma_{\mathrm{HCO}_{3}^{-}} 10^{-p H}}{K_{1}}$

The bicarbonate ion concentration, $\left[\mathrm{HCO}_{3}^{-}\right]$in molar units, and the $\mathrm{pH}$ were extracted from the available data bases. The ionization constant, $\mathrm{K}_{1}$, of carbonic acid is dependent on temperature; a temperature-fitting function provided by Langmuir (1997) was used in all calculations. In addition, the calculation requires the activity coefficient, $\gamma$, which can be calculated from the ionic strength using the Debye-Hückel relationship if an estimate can be obtained of the ionic strength

Ionic strength can be easily calculated from the specific conductance, a parameter that is frequently measured as a proxy for hardness and total dissolved solids (e.g. Krawczyk \& Ford 2006). A new estimate for the relationship was obtained from a data base (Jacobson, 1973) containing analyses from 60 karst springs, limestone wells, and dolomite wells in the Ordovician carbonate rocks in central Pennsylvania, USA. Measured ion concentrations and specific conductance allowed the calculation of a linear regression (Eqn. 5) that fit all of the data to an $\mathrm{R}^{2}$ of 0.99 .

$$
I=1.697 \times 10^{-5} S p c-14.7 \times 10^{-5}
$$

Ionic strength is in moles/L; Spc is in $\mu \mathrm{S} / \mathrm{cm}$. The data points derived from springs, limestone wells, and dolomite wells all had about the same small scatter around the same linear fitting line showing that the relationship is independent of the $\mathrm{Ca} / \mathrm{Mg}$ ratio and saturation state of the waters.

Substituting (3) into (4) and neglecting $\mathrm{CO}_{3}{ }^{2-}$, we obtain the total concentration of dissolved carbon in molar units.

$[$ Carbon $]=\left[\mathrm{HCO}_{3}^{-}\right]\left\{1+\frac{\left[\mathrm{HCO}_{3}^{-}\right] \gamma_{\mathrm{HCO}_{3}^{-}} 10^{-p H}}{K_{1}}\right\}$

Multiplying [Carbon] by 12.011, the atomic weight of carbon, gives the carbon loading in units of $\mathrm{g} / \mathrm{L}$ (or $\left.\mathrm{kg} / \mathrm{m}^{3}\right)$.

The total carbon flux, $\mathrm{F}_{\mathrm{C}}$, in units of $\mathrm{kg} / \mathrm{day}$, is then given by

$F_{\mathrm{c}}=17.012 C_{\mathrm{HCO}_{3}^{-}}\left|1+\frac{\left[\mathrm{HCO}_{3}^{-}\right] \gamma_{\mathrm{HCO}_{3}^{-}} 10^{-\mathrm{pH}}}{K_{1}}\right| Q$

where $\mathrm{Q}$ is the spring discharge is $\mathrm{m}^{3} / \mathrm{sec}$ and the bicarbonate ion concentration, $\mathrm{C}_{\mathrm{HCO} 3}$, is in units of $\mathrm{mg} / \mathrm{L}$, the value that is typically reported. The numerical coefficient contains atomic and molecular weights and necessary unit conversions $(12.011 \times 86,400) /(1000 \times 61.016)$.

It may be noted that the calculated carbon concentrations and fluxes do not depend on the degree of saturation with respect to calcite or dolomite. It is thus possible to meaningfully compare seepage and drip waters that are often saturated with carbonates with spring and cave stream waters which are frequently undersaturated.

\section{CARBON FLUXES WITHIN KARST AQUIFERS}

\section{CARBON IN THE EPIKARST}

As a source, the epikarst is remarkably complicated. $\mathrm{CO}_{2}$ is produced by exhalation through plant roots, by decaying organic material, and other microbial processes. The rate of $\mathrm{CO}_{2}$ production depends of soil characteristics, on the vegetative cover, and is sensitive to both moisture conditions and temperature. Only a por- tion of the generated $\mathrm{CO}_{2}$ is swept into the subsurface by infiltrating precipitation; much is lost by upward diffusion back into the atmosphere. The many complications of soil $\mathrm{CO}_{2}$ are discussed in some detail by Jakucs (1977). There have been several efforts to model $\mathrm{CO}_{2}$ production on both global scale (Brook et al. 1983; Gunn 1984) and site-specific scales with coupled rate 
equations (Šimůnek \& Suarez 1993; Suarez \& Šimůnek 1993).

The seasonal variability of soil $\mathrm{CO}_{2}$ is illustrated with the comprehensive data of De Jong and Schappert (1972) (Fig. 2). Their data were collected in a non-karstic prairie soil in Canada. Several features stand out. $\mathrm{CO}_{2}$

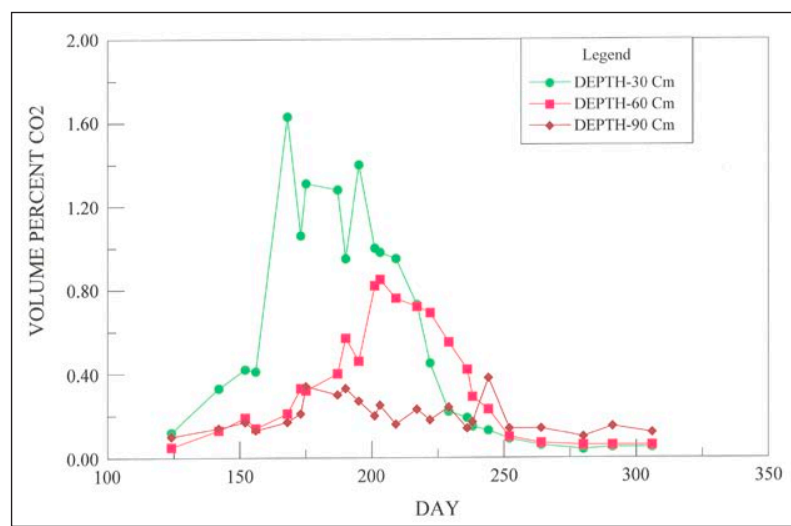

Fig. 2: Seasonal variation in $\mathrm{CO}_{2}$ concentration in a prairie soil measured at the designated depths. Days are counted from January 1. Raw data taken from de Jong and Schappert (1972).

concentrations range up to more than one percent during the growing season but fall to only a few times atmospheric background as the growing season fades into winter. The $\mathrm{CO}_{2}$ concentration decreases with depth and the seasonal oscillation decreases and shifts to later in the year. At $90 \mathrm{~cm}$ depth, the seasonal variation has essentially disappeared. A similar range was observed in a forest soil in the sub-tropical climate of Pigeon Mountain, Georgia (Kiefer 1990) where low $\mathrm{CO}_{2}$ concentrations in the non-growing season were also observed (Dyer \& Brook 1991). Data collected from a wide variety of locations gave similar results (Miotke 1974). Tropical soils tend to contain higher $\mathrm{CO}_{2}$ concentrations, 5 volume percent or higher in some locations measured in Malaysia (Crowther, 1984).

The many measurements of soil $\mathrm{CO}_{2}$ concentration represent the steady-state result of three competing processes: (1) the rate of production of $\mathrm{CO}_{2}$ by a variety of processes, $\mathrm{Pr}$, (2) the rate at which $\mathrm{CO}_{2}$ is dissolved in infiltration water and carried down to the reaction zone at the bedrock contact, $\mathrm{F}_{\mathrm{i}}$, and (3) the rate at which $\mathrm{CO}_{2}$ diffuses upward to be lost to the atmosphere, $F_{D}$.

Soil $\mathrm{CO}_{2}=\frac{d \operatorname{Pr}}{d t}-a \frac{d F_{i}}{d t}-b \frac{d F_{D}}{d t}$

The coefficients $\mathrm{a}$ and $\mathrm{b}$ describe the relative proportions of $\mathrm{CO}_{2}$ lost by the two routes, parameters that are generally not known. They would describe the frac- tion of $\mathrm{CO}_{2}$ available for dissolution of limestone and thus potentially sequestered. The flux, $\mathrm{F}_{\mathrm{D}}$, represents carbon returned to the growing plant/dead plant/decay closed cycle.

\section{SINKING STREAM INPUTS}

Sinking streams contain both surface runoff and ground water discharging from the stream banks. If the $\mathrm{CO}_{2}$ flux from groundwater discharging along the bank is high, the flowing free surface stream may degas $\mathrm{CO}_{2}$ before the stream reaches its swallet. Sinking streams usually input their water and dissolved $\mathrm{CO}_{2}$ load directly into the conduit system where it moves rapidly through the subsurface to a spring

Relatively few analyses of sinking stream waters are available. Data from three such streams are presented in Fig. 3. The Logan Gap stream, in central Pennsylvania,

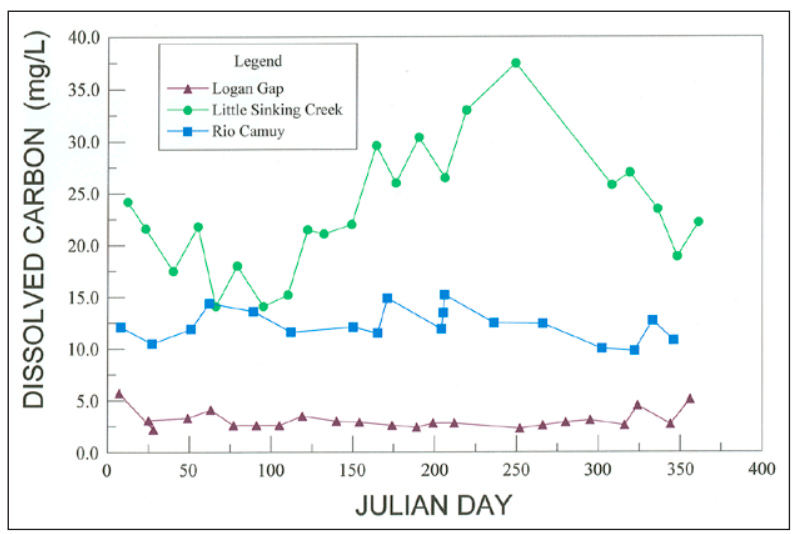

Fig. 3: Dissolved carbon loading for three sinking streams. All measurements made near the stream swallets. Logan Gap: 19611962; Little Sinking Creek: 1972-1973 (Hess 1974); Rio Camuy: 1980-1984 (Troester 1994). Data are arranged by Julian day although not all data were collected in the same year.

flows across Silurian sandstones and shales, then sinks into a swallet at the contact with Ordovician carbonates. Little Sinking Creek rises on the carbonate-rich Salem and Warsaw formations on the southern edge of the Sinkhole Plain in the Central Kentucky Karst and flows on carbonates for some distance before sinking into the lower St. Louis Limestone. Rio Camuy rises on the Tertiary volcanics that make up the core of the Island of Puerto Rico. The river sinks into Tertiary carbonates where it flows through the Rio Camuy Cave System to a resurgence cave and then as a surface river to the coast.

The carbon loading in sinking streams is very strongly dependent on the details of the specific catchment. Mountain streams from sandstone and shale carry only a few $\mathrm{mg} / \mathrm{L}$ of carbon. Even a tropical basin carries little carbon from a catchment located on volcanic rocks. 
The carbon loading of both non-carbonate rock streams is essentially constant with respect to season, temperature, and discharge. The dissolved carbon in Little Sinking Creek, a partly carbonate stream, exhibits a seasonal cycle with a minimum in late March and a maximum in early September.

\section{CARBON RELEASE BY SPELEOTHEM DEPOSITION}

The $\mathrm{CO}_{2}$ partial pressures in air-filled caves in the vadose zone are typically ten or more times higher than the atmospheric $\mathrm{CO}_{2}$ partial pressure and vary widely between caves and between locations within the same cave (Ek \& Gewalt 1985; Kempe et al. 1998). There is a seasonal variation in the $\mathrm{CO}_{2}$ concentration in cave atmospheres that reflects the seasonal cycle in $\mathrm{CO}_{2}$ production in the epikarst (Troester \& White 1984). The vadose seepage waters percolating downward from the epikarst typically have $\mathrm{CO}_{2}$ partial pressures that are higher than cave atmospheres. As a result, vadose seepage waters de-gas $\mathrm{CO}_{2}$ into the cave atmosphere with concurrent deposition of calcite (or aragonite) onto growing speleothems. The fraction of the $\mathrm{CO}_{2}$ in the cave air that makes its way back to the surface atmosphere represents one of the leaks in the karst system. The observed $\mathrm{CO}_{2}$ concentrations represent a balance between the rate of $\mathrm{CO}_{2}$ degassing from seepage waters and the rate of $\mathrm{CO}_{2}$ loss by air exchange with the surface.

Because of the application of speleothems as paleoclimate archives, there is much contemporary interest in dripwater. Measurements are difficult because the chemistry, particularly the $\mathrm{CO}_{2}$ content, changes rapidly by degassing when the drips emerge into the cave atmosphere. In a classic paper, Holland et al. (1964) measured the water chemistry of 47 drip points and drip pools in Luray Caverns, Page County, Virginia. A selection of these measurements that were sufficiently complete for calculation gave dissolved carbon loadings in the range of 70 to $140 \mathrm{mg} / \mathrm{L}$. Dripwater chemistry from Cave Without A
Name, Kendall County, Texas (Veni 1997) (Fig. 4) produced a cool season carbon loading only slightly greater than that of the sinking streams, There was a warm season maximum in this relatively arid region that reached to the lower end of the range measured in Luray Caverns, in an area with higher rainfall and thicker soils.

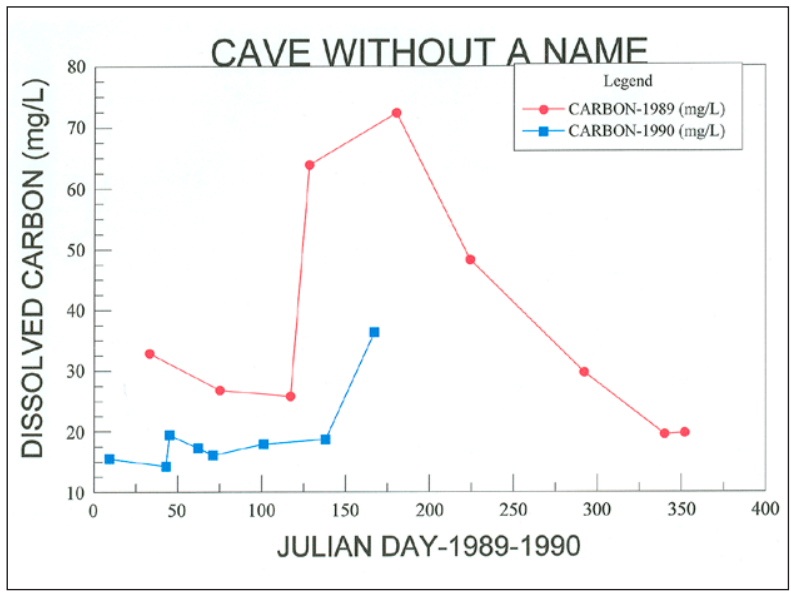

Fig. 4: Dissolved carbon loading in dripwater from Cave Without a Name, Kendall County, Texas. Segments of two Julian years are included. Original data drawn from Veni (1997).

Two factors indicate that speleothem precipitation is not a major loss term in the carbon flux. (1) Although the seepage waters carry a high carbon loading, only a fraction of the load is deposited as speleothem calcite. (2) Air-filled conduits intercept only a small fraction of the water and dissolved carbon descending from the epikarst. Worthington et al. (2000) have estimated that conduits underlie only on the order of one percent of karstic aquifers. Although the conduit systems act as master drains for the aquifer relatively little of the infiltration water from the epikarst passes through an open conduit.

\section{CARBON FLUXES IN KARST SPRINGS}

\section{SEASONAL CYCLES}

Rarely does an investigation of karst springs provide chemical analyses of the water matched with quantitative measurement of discharge. An exceptionally good data set was collected from Tippery Cave, Huntingdon County, Pennsylvania (Hull 1980) that provides 69 oneweek intervals with carefully measured discharge (Fig. 5). Tippery Spring is fed by a conduit system resulting in a hydrograph with many individual storm peaks. The hydrograph peak at week 47 (February 17, 1976) reached a discharge of $1088 \mathrm{~L} / \mathrm{sec}$. In contrast, the carbon loading was only weakly dependent on discharge. The intense peak at week 47 produced only a dilution effect of about $50 \%$ of the carbon loading. The carbon loading shows a broad seasonal maximum at about week 22 (late August). 


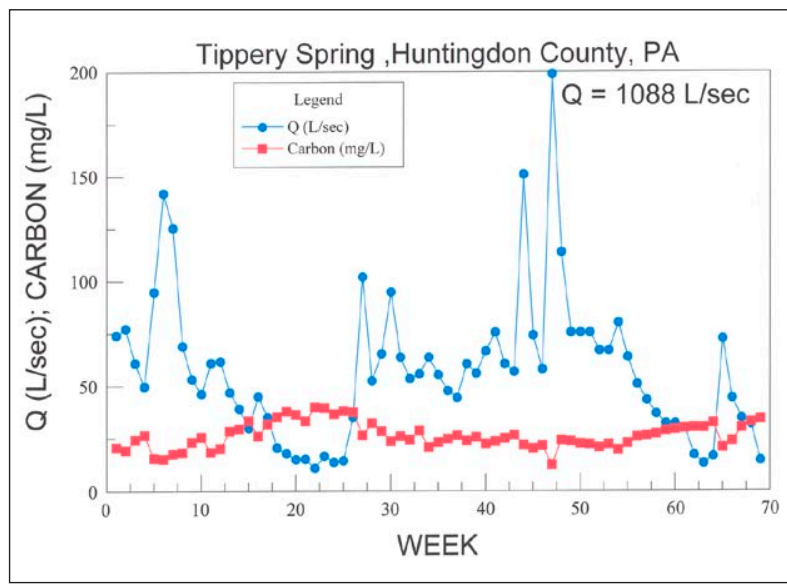

Fig. 5: Hydrograph and carbon loading for Tippery Spring, Huntingdon County, Pennsylvania. Week 1 begins April 1, 1975. Note that the hydrograph peak on week 47 is for a severe storm with a discharge of $1088 \mathrm{~L} / \mathrm{sec}$. Original data drawn from Hull (1980).

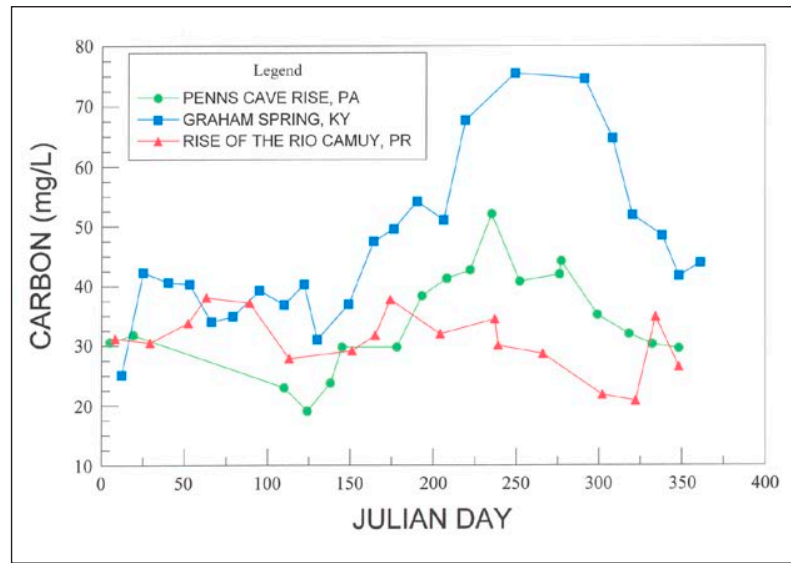

Fig. 6: Carbon loadings in three large karst springs. Data for Penn's Cave Rise from Shuster (1970). Data for Graham Spring from Hess (1974). Data for the Rise of the Rio Camuy from Troester (1994).

The seasonal effect in the carbon loading is demonstrated with data on three karst springs (Fig. 6). The Penn's Cave rise is the discharge point for a large carbonate basin that includes both infiltration and sinkhole inputs in a karst valley and a component of sandstone mountain runoff from streams that sink along the valley margins. There is a broad maximum that peaks at about Julian day 250 (early September). A much more prominent seasonal maximum occurs in the carbon loading of Graham Spring. Graham Spring, near Bowling Green, Kentucky, drains a large area of the Sinkhole Plain south of Mammoth Cave. There is some sinking stream input but most of the water originates from infiltration and sinkhole drains in the karst. The maximum is shifted slightly to late September compared with the Pennsylvania data. In contrast, the carbon loading in the rise of the
Rio Camuy in Puerto Rico has no significant seasonal dependence. Rather than corresponding to the maxima in the temperate climate karst data, the Rio Camuy data are very similar to the loadings measured for the other springs during the winter season.

\section{STORM FLOWS}

Storm water moves though the conduit system of karst aquifers as a pulse of fresh surface water. Storm effects on aquifer chemistry are varied. Storm pulses dilute the dissolved carbonates resulting in a dip in hardness during storm events. In contrast, storm pulses may flush soil contaminants resulting spikes of nitrate or agricultural chemicals during storm events. There appears to be only a small response of the carbon flux to storm pulses in the data collected at Tippery Spring. The intense storm shown on Fig. 5 where the discharge rose to about 50 times the base flow value resulted in only about a factor of two decrease in the carbon loading.

Rock Spring, Centre County, Pennsylvania happened to be gauged and was being sampled on a regular basis when the Hurricane Agnes storm swept across Pennsylania in June, 1972 (Jacobson, 1973). Rock Spring is fed by a strike-oriented conduit with a large recharge from mountain runoff. The Agnes storm produced a very flashy hydrograph (Fig. 7-A). The carbon loading, however, dipped only slightly as the storm pulse passed (Fig. 7-B). The carbon flux, therefore, is dominated by the storm hydrograph and also exhibits a large peak coincident with the hydrograph peak (Fig. 7-B).

\section{SPRING RUNS, $\mathrm{CO}_{2}$ DEGASSING, AND TUFA DEPOSITION}

Karst spring water is usually undersaturated when it is drains from a conduit system and may be close to saturation when it drains from a fracture aquifer. In most spring waters, the carbon dioxide pressure is well above the atmospheric background. As the water from the spring flows down the spring run, carbon dioxide is degassed, the $\mathrm{pH}$ of the water rises as does the saturation index. An example (Shuster 1970) (Fig. 8), measured on Elk Creek which rises from a large conduit-fed spring, shows that $\mathrm{pH}$ rises in an S-shaped curve reaching a steady state value about $800 \mathrm{~m}$ below the spring mouth. $\mathrm{Ca}^{2+}$ and bicarbonate ion concentrations remain constant implying that dissolved $\mathrm{CO}_{2}$ is lost but no carbonate has precipitated. The saturation index also rises on an S-shaped curve reaching a steady state value of about +0.3 , less than the +0.5 supersaturation typically needed to nucleate calcite precipitation.

The concentration of dissolved carbon at the spring mouth was calculated to be $25.9 \mathrm{mg} / \mathrm{L}$ which decreased to $24.2 \mathrm{mg} / \mathrm{L}$ downstream. For this specific example, 

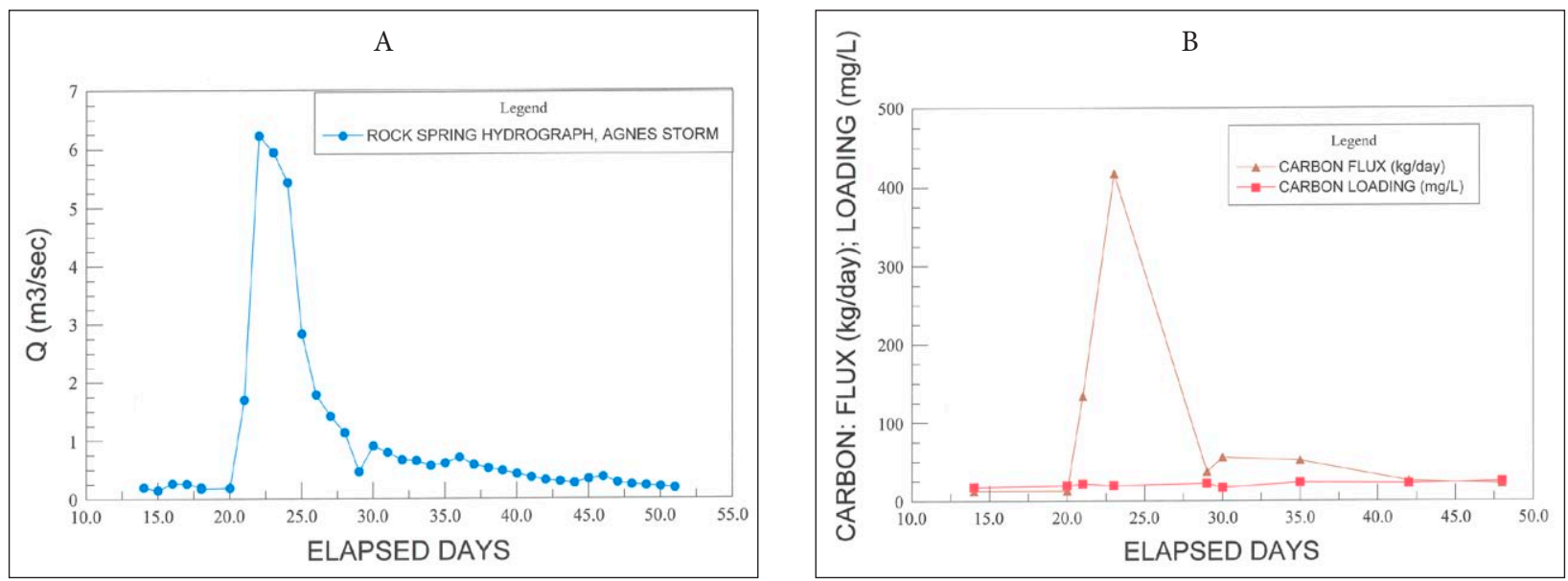

Fig. 7: (A) Hydrograph for Rock Spring, Centre County, Pennsylvania during the Hurricane Agnes storm in June, 1972. Elapsed days are measured from June 1. (B) Carbon loading and carbon flux from Rock Spring during Hurricane Agnes. Original data drawn from Jacobson (1973).

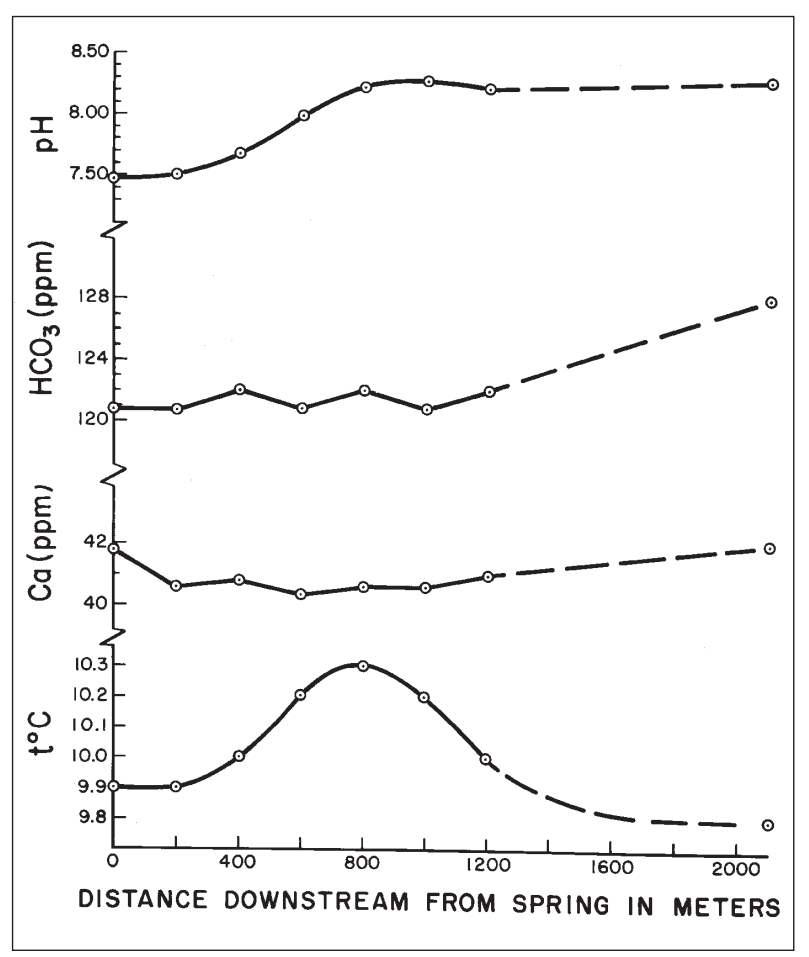

6-7 \% of the dissolved carbon was lost to the atmosphere by $\mathrm{CO}_{2}$-degassing.

Many karst streams, particularly those in tropical regions, precipitate excess carbonate as tufa deposits (Ford \& Pedley 1996). This reverses the carbonate dissolution chemistry and releases $\mathrm{CO}_{2}$ into the atmosphere. Tufa deposition is an additional loss term in the overall carbon balance. $\mathrm{CO}_{2}$ degassing from spring runs raises the $\mathrm{pH}$ and the saturation index. If the $\mathrm{CO}_{2}$ pressure in the stream water reaches the atmospheric value before the saturation index reaches the critical value for carbonate precipitation, the reaction will stop, the steadystate condition illustrated in Fig. 8. However, if the $\mathrm{CO}_{2}$ partial pressures and dissolved carbonate concentrations are high, as is typical of tropical karst, the saturation index will reach the critical value before all excess $\mathrm{CO}_{2}$ is degasses and carbonates will be precipitated (White 1997).

Fig. 8: Changes is $\mathrm{pH}$ and carbonate species along the spring run of Elk Creek Rise in Centre County, Pennsylvania. From Shuster (1970).

\section{CONCLUSIONS}

It has been suggested that the reaction of carbon dioxide with carbonate rocks in karst aquifers is a potential sink for atmospheric $\mathrm{CO}_{2}$ and should be considered by those who are constructing global carbon cycles. This paper ex- amines some of the details in the flux of carbon through karst aquifers. The flux of carbon leaving a karst drainage basin can be described in mass balance terms: 


$$
\begin{aligned}
& \operatorname{FLUX}_{\text {Exit }}=1 / 2\left[C_{\text {Epk }}+C_{\text {Atm }}\right] Q_{i}+C_{S S} Q_{S S}-C_{\text {Spm }} Q_{i} f_{\text {Con }} \\
& -C_{\text {Run }} Q_{\text {Spr }}-C_{\text {Tuf }} Q_{\text {Spr }}
\end{aligned}
$$

The $\mathrm{C}$ terms are carbon loadings in units of mass/ unit volume with subscripts Epk = epikarst, Atm $=$ atmospheric, $\mathrm{Spm}=$ speleothem, SS = sinking stream, Run $=$ spring run, Tuf $=$ tufa. The $\mathrm{Q}$ terms are water flows in units of volume/unit time. $Q_{i}=$ overall infiltration recharge into the karst aquifer; $\mathrm{Q}_{\mathrm{SS}}$ is total recharge from sinking streams; $\mathrm{Q}_{\mathrm{spr}}$ is the discharge from the springs draining the karst aquifer. $\mathrm{f}_{\text {Con }}$ is the fraction of the total karst area underlain by air-filled conduits. The carbon loading terms can usually be estimated from available geochemical data. Data for the Q-terms are sparse.

Carbon loadings vary with season in temperate karst but show little variation in tropical karst. They are strongly dependent on the details of the specific karst drainage basin but are only weakly dependent on discharge. Storm flows dilute the carbon loadings but usually by a factor of two or less. Carbon fluxes essentially scale with discharge.

Speleothem precipitation is a loss term but a small one because of the small fraction of the aquifer that is actually underlain by air-filled conduits. Degassing from spring runs represents a loss of $5-10$ percent of the carbon load with an additional loss if the spring run precipitates tufa deposits.

Overall, it appears that although karst systems are leaky in the sense that a fraction of the extracted $\mathrm{CO}_{2}$ is returned to the atmosphere, they do represent a carbon sink that should be considered in global models.

\section{ACKNOWLEDGEMENTS}

As cited in the text, this study draws heavily on data collected in the course of the thesis research of many Penn State students who, themselves, had quite differ- ent objectives. Theses are a useful repository of raw data which rarely appear in the published versions of the dissertation research.

\section{REFERENCES}

Brook, G.A., Folkoff, M.E. \& E.O. Box, 1983: A world model of soil carbon dioxide.- Earth Surface Processes and Landforms, 8, 79-88.

Crowther, J., 1984: Soil carbon dioxide and weathering potentials in tropical karst terrain, peninsular Malaysia: A preliminary model.- Earth Surface Processes and Landforms, 9, 397-407.

De Jong, E. \& H.J.V. Schappert, 1972: Calculation of soil respiration and activity from $\mathrm{CO}_{2}$ profiles in the soil.- Soil Science, 113, 328-333.

Drever, J.I., 1997: The Geochemistry of Natural Waters.Prentice Hall, pp. 436, Upper Saddle River, NJ.

Dyer, J.M. \& G.A. Brook, 1991: Spatial and temporal variations in temperate forest soil carbon dioxide during the non-growing season.- Earth Surface Processes and Landforms, 16, 411-426.

Ek, C. \& M. Gewelt, 1985: Carbon dioxide in cave atmospheres. New results in Belgium and comparison with some other countries.- Earth Surface Processes and Landforms, 10, 173-187.
Ford, T.D. \& H.M. Pedley, 1996: A review of tufa and travertine deposits of the world.- Earth Science Reviews, 41, 117-175.

Franck, S., Kossacki, K. \& C. Bounama, 1999: Modelling the global carbon cycle for the past and future evolution of the earth system.- Chemical Geology, 159, 305-317.

Gaillardet, J., Dupré, B., Louvat, P. \& C.J. Allègre, 1999: Global silicate weathering and $\mathrm{CO}_{2}$ consumption rates deduced from the chemistry of large rivers.Chemical Geology, 159, 3-30.

Gombert, P., 2002: Role of karstic dissolution in global carbon cycle.- Global and Planetary Change, 33, 177-184.

Gunn, J., 1984: A world model of soil carbon dioxide: A discussion.- Earth Surface Processes and Landforms, 9, 83-84.

Hess, J.W., 1974: Hydrochemical investigations of the central Kentucky karst aquifer system.- Ph.D. Thesis, The Pennsylvania State University, pp. 218. 
Holland, H.D., Kirsipu, T.V., Huebner, J.S., \& U.M. Oxburgh, 1964: On some aspects of the chemical evolution of cave waters.- Journal of Geology, 72, 36-67.

Hull, L.C., 1980: Mechanisms controlling the inorganic and isotopic geochemistry of springs in a carbonate terrain.- Ph.D. Thesis, The Pennsylvania State University, pp. 259.

Jacobson, R.L., 1973: Controls on the quality of some carbonate ground waters: Dissociation constants of calcite and $\mathrm{CaHCO}_{3}^{+}$from 0 to $50{ }^{\circ} \mathrm{C}$.- $\mathrm{PhD}$ thesis. The Pennsylvania State University, pp. 131.

Jakucs, L., 1977: Morphogenetics of Karst Regions.- John Wiley, pp. 284, New York, NY.

Kempe, S., Neander, F., Hartmann, J. \& W. Klughart, 1998: $\mathrm{CO}_{2}$-Druck der Luft in der "Höhle ohne Namen”, Steinamwasser (Nördliche Frankenalb).- Mitteilungen der Verbandes der deuschen Höhlen- und Karstforscher, 44, 2, 39-44.

Kiefer, R.H., 1990: Soil carbon dioxide concentrations and climate in a humid subtropical environment.Professional Geographer, 42, 182-194.

Krawczyk, W.E. \& D.C. Ford, 2006: Correlating specific conductivity with total hardness in limestone and dolomite karst waters.- Earth Surface Processes and Landforms, 31, 221-234.

Kump, L.R., Brantley, S.L. \& M.S. Arthur, 2000: Chemical weathering, atmospheric $\mathrm{CO}_{2}$, and climate.- Annual Reviews of Earth and Planetary Science, 28, 611-667.

Langmuir, D., 1997: Aqueous Environmental Geochemistry.- Prentice Hall, pp. 600, Upper Saddle River, NJ.

Liu, Z. \& J. Zhao, 2000: Contribution of carbonate rock weathering to the atmospheric $\mathrm{CO}_{2}$ sink.- Environmental Geology, 39, 1053-1058.

Liu, Z., Dreybrodt, W. \& H. Liu, 2011: Atmospheric $\mathrm{CO}_{2}$ sink: Silicate weathering or carbonate weathering?Applied Geochemistry, 26, S292-S294.

Miotke, F.-D., 1974: Carbon dioxide and the soil atmosphere.- Abhandlungen zur Karst-und Höhlenkunde, A9, pp. 49.

Moosdorf, N., Hartmann, J., Lauerwald, R., Haedorn, B. \& S. Kempe, 2011: Atmospheric $\mathrm{CO}_{2}$ consumption by chemical weathering in North America.- Geochimica et Cosmochimica Acta, 75, 7829-7854.
Shuster, E.T., 1970: Seasonal variations in carbonate spring water chemistry related to ground water flow. M.S. Thesis, The Pennsylvania State University, pp. 148.

Šimůnek, J. \& D.L. Suarez, 1993: Modeling of carbon dioxide transport and production in soil 1. Model development.- Water Resources Research, 29, 487497.

Suarez, D.L. \& J. Šimůnek, 1993: Modeling of carbon dioxide transport and production in soil 2. Parameter selection, sensitivity analysis, and comparison of model predictions to field data.- Water Resources Research, 29, 499-517.

Troester, J.W., 1994: The geochemistry, hydrogeology, and geomorphology of the Rio Camuy drainage basin, Puerto Rico: A humid tropical karst.- Ph.D. Thesis, The Pennsylvania State University, pp. 344.

Troester, J.W. \& W.B. White, 1984: Seasonal fluctuations in the carbon dioxide partial pressure in a cave atmosphere.- Water Resources Research, 20, 153156.

Veni, G., 1997: Geomorphology, hydrogeology, geochemistry, and evolution of the karstic Lower Glen Rose aquifer, south-central Texas.- Texas Speleological Survey Monographs 1, pp. 409.

White, W.B., 1988: Geomorphology and Hydrology of Karst Terrains.- Oxford University Press, pp. 464, New York.

White, W.B., 1997: Thermodynamic equilibrium, kinetics, activation barriers, and reaction mechanisms for chemical reactions in karst terrains.- Environmental Geology, 30, 46-58.

Wood, W.W., 1985: Origin of caves and other solution openings in the unsaturated (vadose) zone of carbonate rocks: A model for $\mathrm{CO}_{2}$ generation.- Geology, 13, 822-824.

Worthington, S.R.H., Ford, D.C. \& G.J. Davies, 2000: Matrix, fracture and channel components of storage and flow in a Paleozoic limestone aquifer. In: Sasowsky, I.D. \& C.M. Wicks (eds.) Groundwater Flow and Contaminant Transport in Carbonate Aquifers. A.A. Balkem, pp. 113-128, Rotterdam. 